\title{
Facebook Usage of Sri Lankan Consumers: Consumption Perspective of Social Media \\ Tharindu Rathnayake ${ }^{1^{*}}$ and Dilan Rathnayake ${ }^{2}$ \\ ${ }^{1}$ Department of Management Studies, Faculty of Humanities and Social Sciences, The Open University of Sri Lanka, Sri Lanka \\ ${ }^{2}$ Department of Marketing Management, Faculty of Management Studies and Commerce, University of Sri Jayewardenepura, Sri Lanka
}

"Corresponding author: Tharindu Rathnayake, Department of Management Studies, Faculty of Humanities and Social Sciences, The Open University of Sri Lanka, Sri Lanka, Tel: 0412222943; E-mail: tharindu.thr@gmail.com

Received date: April 12, 2018; Accepted date: April 23, 2018; Published date: April 30, 2018

Copyright: ( $) 2018$ Rathnayake T, et al. This is an open-access article distributed under the terms of the Creative Commons Attribution License, which permits unrestricted use, distribution, and reproduction in any medium, provided the original author and source are credited.

\begin{abstract}
Social media has become pervasive, impacting the social and cultural fabric of our society and changing the nature of social relationships. Facebook, being the second most visited website in the world and No: 01 in Sri Lanka, could be identified as a special kind of addiction today where an average user browses Facebook at least for 30 minutes a day from computers or smart devices and gets exposed to diverse content on Facebook as a habit. Marlatt, Baer, Donovan, and Kivlahan, defined addictive behavior as "a repetitive habit pattern that increases the risk of disease and/or associated personal and social problems" or "the behavior continues to occur despite volitional attempts to abstain or moderate use". Compulsive, excessive, impulsive, uncontrolled, and indulgent were also listed instead of the term "addictive". In this study, the researcher has attempted to investigate the relationship of compulsive consumption behavior on Facebook has with the demographic factors of individuals.
\end{abstract}

Keywords: Social media; Compulsive consumption; Facebook addiction

\section{Introduction}

The web has rapidly enhanced the capacity for people to interact with one another without the boundaries of their locationMore specifically, social media has become one of the major platforms, which enable people to interact with each other across geographical boundaries. Though, there are numerous social network sites, Facebook is considered to be the most popular social media platform. Facebook, being the second most visited website in the world and number one in Sri Lanka, could beidentified as a special kind of addiction today where an average user browses Facebook at least for 30 minutes a day from computers or smart devices and gets exposed to diverse content on Facebook as a habitSince the literature suggests that individuals deal with social media content in three ways; consumption, participation and production, it could be suspected that excessive usage of Facebook could lead to addictive consumption which may derive numerous social issues. It is an accepted fact that an addiction is known to destroy human beings and their relationships and Facebook addiction is no exception to thisFurther, it is evident that there has been a significant lack of empirical research in this regard from social marketing perspective despite the fact that it has been examined in psychological viewpoint [1-5].

\section{Objectives}

Concerning the need of a study to examine the Facebook addiction from a social marketing perspective, this study aimed to examine the level of addictive consumption of Facebook among Sri Lankan consumers. Further, it attempted to examine variations of Facebook addiction among various demographical characteristic of consumers.

\section{Methods}

The main purpose of the study is to examine the relationship between demographic factors of individuals and compulsive consumption behavior on Facebook with special reference to Sri Lankan Facebook users. As per previous literature, Bergen Facebook Addiction Scale (BFAS) has identified many factors that might have been symptoms of Facebook addiction [2]. As the above research gap explains, there is a need of use salience, mood modification, tolerance, withdrawal, conflict and relapse dimensions to examine the Facebook addiction. The study is descriptive in nature and survey was carried out to test the association between compulsive consumption behavior on gender of individuals. The research was single cross-sectional as data was collected from the sample at a single point time. The unit of analysis was at individual level consumers. Convenience sampling technique was used to select the sample and the sample size was 254 . The survey method was used to collect data and sample data was collected using self-administered questionnaire which was distributed among respondents. Descriptive statistics were generated with the aid of SPSS version 23.

\section{Analysis and Results}

In this section the researcher validate objectives by testing hypothesis developed for each objective by using analysis techniques as appropriate. The first objective is to examine the degree of Facebook addiction among Facebook users in Sri Lanka.

According to Objective 1, the Degree of Facebook addiction is tested by comparing whether the Mean $(\mu)$ of Facebook addiction variable (according to Table 1, Mean of Facebook addiction is 2.84) is significantly less than the test value (3); in the present case. Researcher decided to use 3 as test value because it is neutral score of the scale and to test whether the mean value of Facebook addiction is significantly towards the positive side of the value scale that used to measure all the 
Citation: Tharindu R, Dilan R (2018) Facebook Usage of Sri Lankan Consumers: Consumption Perspective of Social Media. Arts Social Sci J 9:

items in the Facebook addiction variable. (Scale: $1-2.5=$ Normal users,

2.5-3.5=Lightly Addicted, 3.5- 5=Seriously Addicted).

\begin{tabular}{|l|l|l|l|l|l|}
\hline & N statistic & Mean Statistic & Std. Deviation statistic & Skewness statistic & Kurtosis statistic \\
\hline Facebook Addiction & 254 & 2.8451 & 0.84203 & 0.28 & 0.89 \\
\hline Valid N (listwise) & 254 & & & & \\
\hline
\end{tabular}

Table 1: Mean values of scale variables.

According to the Methodology, test appropriate for this measure is one sample t-test.

\begin{tabular}{|c|c|c|c|c|c|c|}
\hline \multicolumn{7}{|l|}{ Test Value $=3$} \\
\hline & \multirow[b]{2}{*}{$\mathbf{t}$} & \multirow[b]{2}{*}{ df } & \multirow[b]{2}{*}{ Sig.(2-tailed) } & \multirow[b]{2}{*}{ Mean Difference } & \multicolumn{2}{|c|}{$95 \%$ confidence interval of the difference } \\
\hline & & & & & Lower & Upper \\
\hline Facebook Addiction & -2.932 & 253 & 0.004 & -0.15492 & -0.259 & -0.0509 \\
\hline
\end{tabular}

Table 2: One sample Test for Degree of Facebook Advertising.

According to the one sample t-test, the significant value is 0.004 which is less than the alpha value of 0.05 . Therefore, the researcher concluded that mean value of Facebook addiction is not equal to 3 among Facebook users in Sri Lanka (Table 2).

\section{Gender and Facebook addiction}

Second objective is to examine significant difference between males and females in terms of Facebook addiction. Independent sample t-test was carried out to see if there are any significant differences in the means of two groups in the variables interest (Table 3).

According to the result of Independent sample t-test, the significant value is 0.000 which is less than the alpha value of 0.05 , the mean value of Facebook addiction of Males is significantly different to mean value of Facebook addiction of Females. Therefore, the researcher concluded that Facebook addiction vary according to the Gender.

\begin{tabular}{|c|c|c|c|c|c|c|c|c|c|}
\hline & \multicolumn{2}{|c|}{$\begin{array}{l}\text { Levene's Test for Equality of } \\
\text { variances }\end{array}$} & \multirow[t]{2}{*}{ t } & \multirow[t]{2}{*}{ df } & \multicolumn{3}{|c|}{ t-test for Equality of Means } & \multirow[t]{2}{*}{ Lower } & \multirow[t]{2}{*}{ Upper } \\
\hline & $\mathbf{F}$ & F Sign. & & & $\begin{array}{l}\text { Sig. } \\
\text { tailed) }\end{array}$ & $\begin{array}{l}\text { Mean } \\
\text { difference }\end{array}$ & $\begin{array}{l}\text { Std. } \\
\text { difference }\end{array} \quad$ Error & & \\
\hline $\begin{array}{l}\text { FBA Equal variances } \\
\text { assumed }\end{array}$ & 2.363 & 0.12551 & 4.014 & 252 & $0 . .000$ & $0 . .41423$ & 0.10319 & 0.21101 & $0 . .61745$ \\
\hline $\begin{array}{l}\text { Equal variances not } \\
\text { assumed }\end{array}$ & & & 4.062 & 249.949 & $0 . .000$ & $0 . .41423$ & $0 . .10197$ & $0 . .21339$ & $0 . .61506$ \\
\hline
\end{tabular}

Table 3: Independent Samples Test.

According to the Table 4, 76 of respondents were Normal users, 88 of respondents were lightly addicted and rest of 90 respondents were seriously addicted to Facebook. Out of 88 of lightly addicted respondents, $21.4 \%$ of respondents are male and $40.4 \%$ of respondents are female. Further, out of 90 of seriously Facebook addicted respondents, $53.6 \%$ of respondents are male and $13.2 \%$ of respondents are female. Therefore researcher concluded that males are lightly or seriously addicted to Facebook rather than females.

\begin{tabular}{|c|c|c|c|c|}
\hline & \multicolumn{3}{|c|}{ Facebook Addiction Categories } & \multirow[t]{2}{*}{ Total } \\
\hline & Lightly Addicted & Moderately Addicted & Highly Addicted & \\
\hline Male count & 30 & 35 & 74 & 140 \\
\hline$\%$ within Gender & $21.40 \%$ & $25 \%$ & $53.60 \%$ & $100 \%$ \\
\hline
\end{tabular}




\begin{tabular}{|l|l|l|l|l|}
\hline Female Count & 46 & 53 & 15 & 114 \\
\hline$\%$ within Gender & $40.40 \%$ & $46.50 \%$ & $13.20 \%$ & $100 \%$ \\
\hline Total Count & 76 & 88 & 90 & 254 \\
\hline
\end{tabular}

Table 4: Gender Facebook addiction categories cross tabulation.

The results revealed that $70 \%$ of the respondents demonstrate addictive consumption of Facebook whereas $20 \%$ of respondents are seriously addicted. Further, it was evident that males are more addicted to use Facebook than females. Moreover, income and level of education seemed to have an impact on addictive consumption of Facebook.

\section{Education level and Facebook addiction}

This section examine whether the education level of the Facebook users has an influence on Facebook addiction, the researcher tests whether the Mean Values of Facebook addiction distributions between social class categories significantly differs to each other. According to Sekaran, Analysis of variance (ANOVA) helps to examine the significant mean differences among more than two groups on an interval or ratio-scaled dependent variable [6,7]. Therefore, appropriate test for this requirement is one way ANOVA test. The variables under interest satisfy the pre-requisites to run the independent sample t-test. (Dependent Variable is a ratio scale, Independent variable has independent Five (05) categories, and Dependent variable is normally distributed under the Five (05) categories.

Skewness and Kurtosis values between $(-2)$ and $(+2)$, data is normally distributed. Therefore, distribution of Facebook addiction between levels of education is normal.

\begin{tabular}{|l|l|l|l|}
\hline Levene Statistic & df1 & df2 & Sig. \\
\hline 4.984 & 4 & 249 & 0.001 \\
\hline
\end{tabular}

Table 5: Test of homogeneity of variances Facebook addiction.

\begin{tabular}{|l|l|l|l|l|}
\hline & Statistic $^{\text {a }}$ & df1 & df2 & Sig. \\
\hline Welch & 1.297 & 4 & 51.947 & 0.283 \\
\hline aAsymptotically F distributed.
\end{tabular}

Table 6: Robust tests of equality of means.

According to Table 5 Levene test statistic (0.001), it is less than a (0.05), which suggests that variances are not equal. Hence, the statistic for ANOVA test is extracted from Welch sig value from the Table 6.

$P$ value $(0.283)$ is greater than $a(0.05)$, therefore, the researcher concluded that Facebook addiction does not significantly vary according to the levels of education of the Facebook users in Sri Lanka.

\section{Discussion/Conclusion}

Findings of the study shed lights on social as well as policy implications. Policy makers in education sector could consider the possibility of students to be addictive in social media usage and educate students about negative consequences of such an addictive behaviour. Further, consultation and mentoring programmes could address the issue of addictive social media consumption and improve individuals' self-control in social media usage. Moreover, effectively designed awareness campaigns may be useful in controlling addictive social media consumption.

Among sample Facebook users, 55.1\% of respondents are Male while $44.9 \%$ of respondents are Female which indicated that there is no much difference between number of users in gender aspect. Although in previous literature mentioned that Females are more in Facebook, current statistics suggest that Males (Mean: 3.0310) have been used
Facebook more than Females (Mean: 2.6168) in Sri Lankan context. As per Socialbakers.com, (which compiles social media statistics globally) higher number of Facebook users in Sri Lanka are males. So, this evidence is further validated by the sample's gender composition. Therefore, researcher can conclude marketing activities on Facebook should consider posting content that are favourable to men than women on Facebook, due to the fact that Male are dominant on Facebook in Sri Lanka. Majority of users (77.2\%) are belong to age 18-27 which means that young generation in Sri Lanka is much engaged in Facebook. This finding is mainly consistent with the findings of Thompson. In Thompson's study, gender differences were examined and according to the findings, females were more likely than males to report spending more time on Facebook. There are many success stories about Facebook usage but at the same time, it also has some negative impacts because of addictive behavior on Facebook. Facebook addiction, excessive use of the Internet or, compulsive consumption behaviour on Facebook has been discussed. The amount of time spent on Facebook, checking social media frequently, spend entire nights on the site, daydreaming about the status updates and comment that have been received are the emerging evidences for negative impact of Facebook addiction. It is essential to understand the level of addiction predict the other factors, because the reality of addictive behavior on Facebook is a growing problem for many users. 
Citation: Tharindu R, Dilan R (2018) Facebook Usage of Sri Lankan Consumers: Consumption Perspective of Social Media. Arts Social Sci J 9: 356. doi:10.4172/2151-6200.1000366

Page 4 of 4

\section{References}

1. Mahmood S, Farooq U (2014) Facebook Addiction: A Study of Big-Five Factors and Academic Performance amongst Students of IUB. Global Journal of Management \& Business Research 14: 55.

2. $\quad$ Andreassen CS, Griffiths MD, Gjertsen SR, Krossbakken E, Kvam S, et al. (2013) The relationships between behavioral addictions and the fivefactor model of personality. Journal of Behavioral Addictions 2: 90-99.

3. Griffiths MD (2012) Internet sex addiction: A review of empirical research. Addiction Research \& Theory 20: 111-124.

4. Marlatt GA, Baer JS, Donovan DM, Kivlahan DR (1988) Addictive Behaviors: Etiology and Treatment. Annu Rev Psychol 39: 223-252.
5. Alavi SS, Maracy MR, Jannatifard F, Eslami M (2011) The effect of psychiatric symptoms on the internet addiction disorder in Isfahan's University students. Journal of Research in Medical Sciences : The Official Journal of Isfahan University of Medical Sciences 16: 793-800.

6. Sekaran (2003) Research methods for Business A Skill-Building Approach Fourth Edition.

7. Malhotra NK (2008) Marketing Research: An Applied Orientation, 5/E. Pearson Education. 